\title{
Economic Impacts of the University of Florida and Affiliated Organizations in 2005-06 ${ }^{1}$
}

Alan W. Hodges, W. David Mulkey, and Thomas J. Stevens ${ }^{2}$

\begin{abstract}
Economic impacts of the University of Florida (UF) and its affiliated organizations on the state's economy were evaluated for the fiscal year 2005-06 using financial data together with regional economic models. Total revenues to UF were \$3.95 billion, including \$1.79 billion from sources outside of Florida. Total spending amounted to \$4.35 billion for University operations, personnel, capital outlays, healthcare services, direct support organizations, students, and campus visitors. Total spending within Florida was \$3.87 billion, of which \$1.66 billion was from sources outside the state. Total output or revenue impacts to the state economy were $\$ 5.85$ billion, including multiplier effects associated with in-state spending from outside sources. Value added impacts to personal income and business profits were \$3.24 billion. The University had direct employment of 34,000 jobs for faculty and staff, including Shands Healthcare, and total statewide employment impacts were 74,894 jobs. Student enrollment in FY 2005-06 was 122,775 student-semesters. There were a total of 3.5 million visitors to campus facilities and academic events, with output impacts of \$9.1 million. In addition, there were 1 million visitors for athletic events. Healthcare services by Shands hospitals, Faculty Practice Associates, and the Colleges of Health Sciences and Veterinary Medicine had output impacts of \$3.39 billion. Teaching, research, and statewide extension education by the Institute of Food and Agricultural Sciences (IFAS) had output impacts of \$283 million. In Alachua County, there was \$2.84 billion in total spending, \$4.95 billion in output impacts, \$2.80 billion in value added impacts, and employment impacts of nearly 65,000 jobs.
\end{abstract}

\footnotetext{
${ }^{1}$ This is EDIS document FE699, a publication of the Food and Resource Economics Department, Florida Cooperative Extension Service, Institute of Food and Agricultural Sciences, University of Florida, Gainesville, FL. Published October 2007. Please visit the EDIS website at http://edis.ifas.ufl.edu.

${ }^{2}$ Alan W. Hodges, Associate Extension Scientist; W. David Mulkey, Professor and Associate Chair; and Thomas J. Stevens, Post Doctoral Associate, Food and Resource Economics Department, Florida Cooperative Extension Service, Institute of Food Agricultural Sciences, University of Florida, Gainesville, FL.

The Institute of Food and Agricultural Sciences (IFAS) is an Equal Opportunity Institution authorized to provide research, educational information, and other services only to individuals and institutions that function with non-discrimination with respect to race, creed, color, religion, age, disability, sex, sexual orientation, marital status, national origin, political opinions, or affiliations. U.S. Department of Agriculture, Cooperative Extension Service, University of Florida, IFAS, Florida A\&M University Cooperative Extension Program, and Boards of County Commissioners. Larry Arrington, Dean.
} 


\section{Acknowledgements}

The study was sponsored by the University of Florida, Office of University Relations, led by Joe Hice and Susan Stewart. Valuable assistance and information used in preparation of this report was provided by the following persons: Ann Becks, Dean of Students Office; Jerry Bigham, Office of the Provost; Laura Barton, College of Medicine, Administrative Affairs; Robert Burton, Gloria Sheffield, Amanda Jobes, and Ted Griswold, University Accounting Services; Jeremy Cynkar, Stephen C. O'Connell Center; Christine Hale, Harn Museum of Art; Mike Hill, Melissa Stuckey, Mary Howard, and Tim Caruthers, University Athletic Association; Leslie Bram, UF Foundation; Catherine Joiner, Office of Finance and Administration; Rebecca Johnson and Adam Smith, UF Division of Continuing Education; Cynthia King, Office of Institutional Planning and Research; Lynn King, College of Dentistry, Continuing Education; Paul Lipori, Cindy Hersdon, and Debra Miller, Shands Health Care; Dottie Haskew, UF/IFAS Budget and Finance; Dale McPherson, Millie Ferrer, and Adam Naim, UF/IFAS Cooperative Extension Service Administration; Beth Miller-Tipton, UF/IFAS Office of Conferences and Institutes; Kathryn Murphy, College of Medicine, Continuing Education; Lori Pennington-Gray, Department of Recreation, Parks, and Tourism; Brian Prindle, Division of Sponsored Research; John Pritcher, Gainesville Visitors and Convention Bureau; Paul Ramey, Florida Museum of Natural History; Deborah Rossi, UF Performing Arts; Kim Schares, UF Human Resource Services; Art Wharton, Department of Pharmacy Practice; and Yanmei Zhang, Division of Student Affairs, Housing, and Resident Education.

\section{Introduction}

The University of Florida (UF) is one of the largest comprehensive public universities in the United States, with enrollment exceeding 50,000 students. Besides the main campus in Gainesville, the University has statewide operations at numerous Research and Education Centers, Shands Hospitals and clinics, and extension offices in all 67 counties of the state. UF has a significant economic impact to the state of Florida through its academic and physical operations; capital outlays; allied organizations; healthcare services; and spending by faculty, staff, students, and visitors. The purpose of this report is to provide an economic impact assessment for UF in the most recent fiscal year (2005-06). Because of differences in the methods used, the results of this analysis are not strictly comparable to previous studies done for 1993-94 and 2002-03. ${ }^{1}$ Furthermore, this study only considers the monetary impacts of the University of Florida on the state's economy, and does not evaluate the intangible benefits of higher education to human capital in the workforce. Another study addressed these issues for the Florida State University System (SUS) as a whole. ${ }^{2}$

\footnotetext{
1 The Economic Impact of the University of Florida on the State of Florida, 2002-03. UF Office of the Provost, Gainesville, FL. Report available at http://www.ir.ufl.edu/economicreport.pdf.

2 Creating Florida's Future: Measuring the Economic Impact of the State University System in Florida. By Tim Lynch, Aaron Smallwood and Mary Lois Barnes, Florida State University, Apr. 2001, 38 pages.
} 


\section{Methods and Information Sources}

This economic impact analysis was based on information provided by a variety of sources. Information on total university revenues and expenditures were taken from the UF Annual Financial Report for FY2005-06 (ending June 30, 2006). ${ }^{3}$ More detailed information on operating and non-operating expenditures, personnel salaries and benefits, and capital outlays were provided by the UF Finance and Accounting Division. Operating expenditures for Shands Hospital, Health Science Center Faculty Practice Associates, Direct Support Organizations such as the Athletic Association and Research Foundation, and other minor business enterprises were obtained from their annual financial statements and from supplemental tables of the UF Financial Report. Data on employment were obtained from the UF Division of Human Resources and the Office of Institutional Planning and Research.

For economic impact analysis, it is important to distinguish the ultimate source of revenues and the destination of expenditures with regard to the study region, since this affects the proportion of total spending that represents new resources and the share of spending that remains in the regional economy, respectively. In this case, the study area was defined as the State of Florida, so the source and use of funds were determined as originating from either inside or outside the state. In general, the share of spending inside of Florida was estimated at the state average percentage of total purchases of the particular commodity or service. Retail spending by students and visitors was assumed to be 100 percent inside the state. Expenditures for UF construction projects were treated as new dollars in the State of Florida, as is conventional for economic impact analysis. The proportion of UF expenditures for operations, payroll, and non-construction capital outlays designated as new dollars was determined by the overall share of UF revenues originating from outside the State.

Total economic impacts of spending by UF, affiliated organizations, students and visitors were estimated with a regional economic model for the state of Florida constructed using the IMPLAN Pro software and associated databases. ${ }^{4}$ This procedure models the specific structure of the state’s economy in terms of the particular mix of industries; linkages between businesses, employees, households, and governments; commodity production and consumption; and trade flows with the rest of the United States and world. It also accounts for taxes paid to local, state, and federal governments, and transfer payments such as welfare and retirement. This approach involves the derivation of economic multipliers which capture the effects of input purchases (indirect effects), and household spending by employees (induced effects) for new resources in the state’s economy, as well as the direct spending and employment associated with UF. Economic multipliers were used to estimate the separate impact measures of output or revenue, employment, and value added. Total economic impacts in this case were estimated with the direct effects multipliers applied to in-state spending amounts, and indirect plus induced effects multipliers applied to in-state spending that was derived from sources outside of Florida, with each expense item assigned to the appropriate IMPLAN sector. The proportions of UF expenditures occurring inside Florida were based on regional purchase coefficients estimated with IMPLAN, which represent the average proportion of a particular

\footnotetext{
${ }^{3}$ University of Florida Annual Financial Report for 2005-06. UF Office of the Controller. 56 pages. March 2007. Available at http://fa.ufl.edu/ga/afr/fy2005-2006_annual_financial_report.pdf.

${ }^{4}$ Minnesota Implan Group, Inc. IMPLAN Pro Social Accounting and Impact Analysis Software, v. 2.1, and 2004 regional data file for Florida. Stillwater, MN, Oct. 2006.
} 
good or service purchased from vendors in the state. Once spending is determined for the University, related organizations, employees, students, and visitors, total impacts can be calculated. In each case, the total impact consists of four distinct parts: 1) direct spending in the state by all UF entities from revenues derived from in-state sources, 2) direct spending in the state from revenues derived from out-of-state sources, 3) indirect spending by businesses on inputs purchased with out-of-state revenues, and 4) induced spending by households associated with out-of-state revenue sources.

The economic impacts of spending by UF employees were estimated based upon typical household personal consumption expenditures for specific income brackets representative of UF faculty, staff, and temporary employees. Impacts of spending by employees of Shands Hospital and other University component units were estimated as part of the overall operating expenses for those units. Expenses for Shands and health science faculty medical practices were assigned to the Implan sectors for Hospitals and Offices of Physicians. Depreciation expenses on fixed assets were excluded from the analysis since this does not represent a cash transaction which has a current local economic impact.

Sales by UF vendors for campus food services, bookstores, and vending concessions were not included in this analysis since their activity is captured in the spending of employees, students, and visitors. Some program expenditures and transfers from Direct Support Organizations (DSO) to the University were included under operating expenses in the UF Annual Financial Report. After reviewing financial reports for each DSO, these operating expenditures were adjusted to remove any amounts for support, transfers, grants, or aid for UF or its students or faculty. Operating expenditures by these organizations were assigned to the Implan sector for Grantmaking, Giving, and Social Advocacy Organizations, with the exception of the University Athletic Association expenditures, which were assigned to the sector for Spectator Sports.

\section{Revenues}

Total revenues to the University of Florida and its affiliated organizations in FY 2005-06 are summarized in Figure 1 and Table 1. Revenues totaled over $\$ 3.95$ billion, and of this amount, an estimated $\$ 1.79$ billion, or 44 percent, was received from sources outside the State of Florida. Shands Hospital and Health Sciences Faculty Practice Associates had revenues of $\$ 1.78$ billion, or 45 percent of total revenues, of which 47 percent were from outside Florida (from health insurance payments and Medicare/Medicaid). State operating and capital improvement appropriations to UF amounted to \$665 million, or 17 percent of total revenues. Grants and contracts for sponsored research activities totaled \$389 million, including those from federal government agencies (\$284 million), state and local governments (\$36 million), and nongovernmental organizations (\$69 million). Student tuition and fees net of scholarships together with federal and state financial aid received amounted to \$250 million. Gifts, donations and endowment contributions amounted to \$259 million. Sales and services for auxiliary enterprises, educational departments, component units, and royalties and licensing fees were \$281 million. Interest and investment income amounted to \$172 million, and miscellaneous other revenues were \$159 million. 
Figure 1. University of Florida Revenues (million \$).

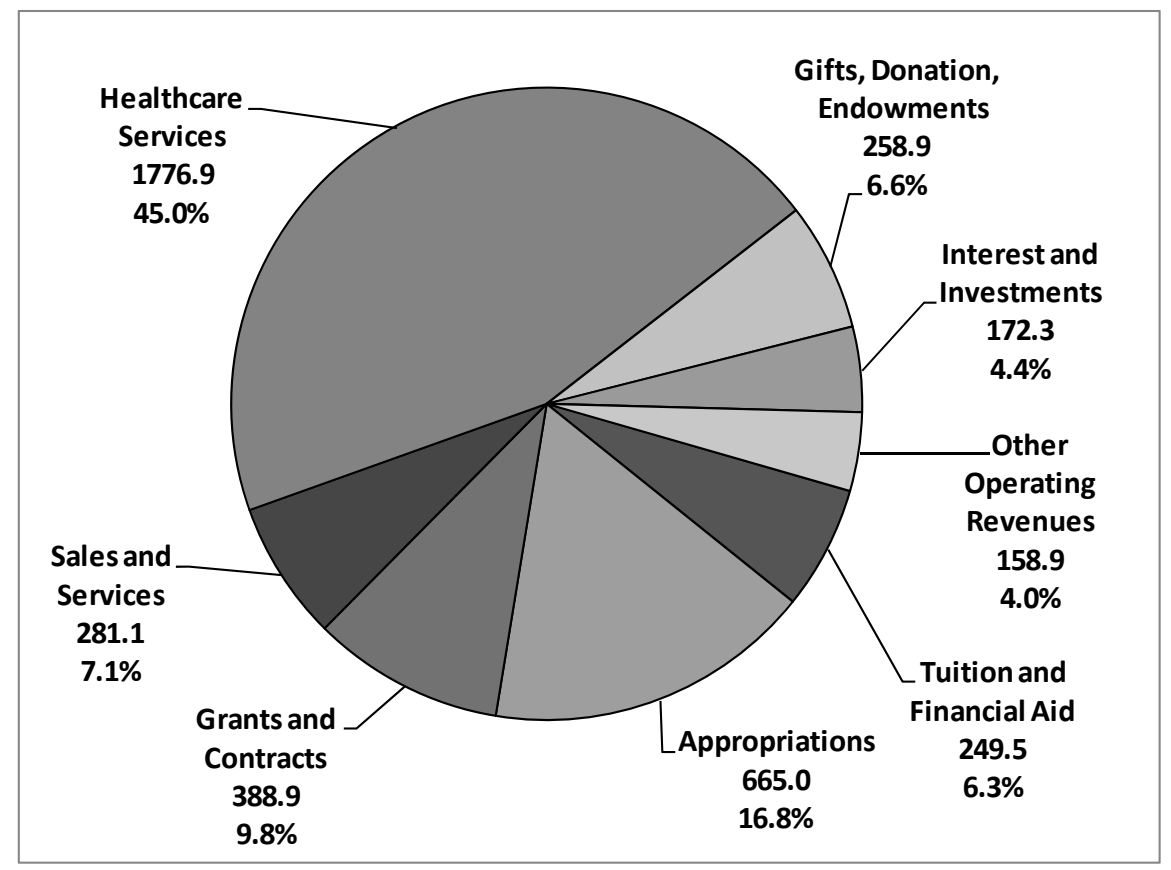

Table 1. Revenues to University of Florida and Affiliated Organizations in FY 2005-06.

\begin{tabular}{|c|c|c|c|c|}
\hline Source & $\begin{array}{c}\text { Total } \\
\text { Amount } \\
\text { (million \$) }\end{array}$ & $\begin{array}{l}\text { Percent } \\
\text { of Total }\end{array}$ & $\begin{array}{c}\text { Amount } \\
\text { from Outside } \\
\text { Florida } \\
\text { (million \$) }\end{array}$ & $\begin{array}{l}\text { Percent of Total } \\
\text { from Outside } \\
\text { Florida }\end{array}$ \\
\hline Tuition and Financial Aid & 249.52 & $6.3 \%$ & 198.43 & $11.1 \%$ \\
\hline Student Tuition and Fees, Net of Scholarships & 152.51 & $3.9 \%$ & 101.42 & $5.7 \%$ \\
\hline Federal and State Financial Aid & 97.01 & $2.5 \%$ & 97.01 & $5.4 \%$ \\
\hline Appropriations & 665.03 & $16.8 \%$ & 0.00 & $0.0 \%$ \\
\hline State of Florida & 596.31 & $15.1 \%$ & 0.00 & $0.0 \%$ \\
\hline Capital Appropriations & 68.72 & $1.7 \%$ & 0.00 & $0.0 \%$ \\
\hline Grants and Contracts & 388.97 & $9.8 \%$ & 324.60 & $18.1 \%$ \\
\hline Federal & 284.35 & $7.2 \%$ & 284.35 & $15.9 \%$ \\
\hline State and Local & 36.12 & $0.9 \%$ & 0.00 & $0.0 \%$ \\
\hline Nongovernmental & 68.50 & $1.7 \%$ & 40.25 & $2.2 \%$ \\
\hline Sales and Services & 281.09 & $7.1 \%$ & 107.22 & $6.0 \%$ \\
\hline Auxiliary Enterprises & 133.55 & $3.4 \%$ & 35.52 & $2.0 \%$ \\
\hline Educational Departments & 53.37 & $1.4 \%$ & 14.20 & $0.8 \%$ \\
\hline Component Units & 49.96 & $1.3 \%$ & 13.29 & $0.7 \%$ \\
\hline Royalties and Licensing Fees & 44.21 & $1.1 \%$ & 44.21 & $2.5 \%$ \\
\hline Healthcare Services & $1,776.92$ & $45.0 \%$ & 835.15 & $46.6 \%$ \\
\hline Shands Hospital & $1,397.44$ & $35.4 \%$ & 656.79 & $36.6 \%$ \\
\hline Faculty Practice Associates & 379.48 & $9.6 \%$ & 178.36 & $9.9 \%$ \\
\hline Gifts, Donations, Endowments & 258.85 & $6.6 \%$ & 62.12 & $3.5 \%$ \\
\hline Gifts and Donations & 125.97 & $3.2 \%$ & 30.23 & $1.7 \%$ \\
\hline Capital Grants, Contracts and Donations & 43.01 & $1.1 \%$ & 10.32 & $0.6 \%$ \\
\hline Additions to Permanent Endowments & 89.87 & $2.3 \%$ & 21.57 & $1.2 \%$ \\
\hline Interest and Investment Income & 172.33 & $4.4 \%$ & 172.33 & $9.6 \%$ \\
\hline Interest on Loans and Notes Receivable & 0.73 & $0.0 \%$ & 0.73 & $0.0 \%$ \\
\hline Investment Income & 171.60 & $4.3 \%$ & 171.60 & $9.6 \%$ \\
\hline Other Operating Revenues & 158.90 & $4.0 \%$ & 93.36 & $5.2 \%$ \\
\hline Total & $3,951.62$ & $100.0 \%$ & $1,793.22$ & $100.0 \%$ \\
\hline
\end{tabular}

Sources: UF Annual Financial Report, 2005-06; UF Finance and Accounting; Shands Hospital, UF Foundation. Note: amounts are net of transfers from direct support organizations. 


\section{Expenditures}

Expenditures by the University of Florida, affiliated organizations, students, and visitors in FY 2005-06 are summarized in Figure 2 and Table 2. Spending on operations and personnel by UF colleges, other academic programs, social and cultural programs, support services, and central administration are shown in Table 3. Total spending, excluding certain non-cash transactions such as depreciation, amounted to $\$ 4.35$ billion, of which $\$ 3.87$ billion was spent within the state of Florida, and of this amount \$1.66 billion was funded from sources outside the state. Spending for University operations amounted to \$431 million, including \$95 million for professional services, \$61 million for supplies, and \$47 million for utilities. Capital outlays totaled \$181 million, including building construction (\$103 million) and equipment purchased (\$57 million). A total of \$126 million in operational spending were from out-of-state sources, and \$112 million in capital spending were treated as new resources to the state.

Expenditures associated with University personnel amounted to \$1.13 billion, including \$924 million in salaries and wages to faculty and staff, and \$204 million in employee benefits and taxes. The salaries and wages were assumed to be used for household personal consumption expenditures. A total of \$411 million in spending by UF personnel was funded from out-of-state sources.

Healthcare services had expenditures amounting to $\$ 1.76$ billion, including Shands Hospitals (\$1.43 billion), Florida Clinical Practice Associates (\$151 million), Jacksonville Physicians (\$149 million), and other health sciences faculty practice associates. These expenditures include wages and benefits paid for hospital and health practice staff, but not the academic portion of salaries for UF medical faculty. A total of \$748 million in healthcare spending was funded from out-of-state sources.

Direct support organizations had operating expenses, excluding outlays supporting the University, of \$102 million, with the largest amounts for the University Athletic Association (\$72 million) and UF Foundation (\$22 million). A total of $\$ 19$ million in spending was funded from out-of-state sources.

Total student spending was estimated at \$630 million, with \$252 million for off-campus housing; \$135 million for food and beverages; \$107 million for books, supplies, and computers; \$78 million for personal items and insurance; \$33 million for clothing; and \$23 million for transportation. A total of \$169 million in student spending was from out-of-state sources.

Spending by campus visitors not affiliated with the University was estimated at \$112 million, with \$74 million for campus attractions and academic events, \$33 million for football games, and \$6 million for other men’s and women’s athletic events. A total of \$24 million in visitor spending originated from out-of-state sources. 
Figure 2. University of Florida Expenditures (million \$)

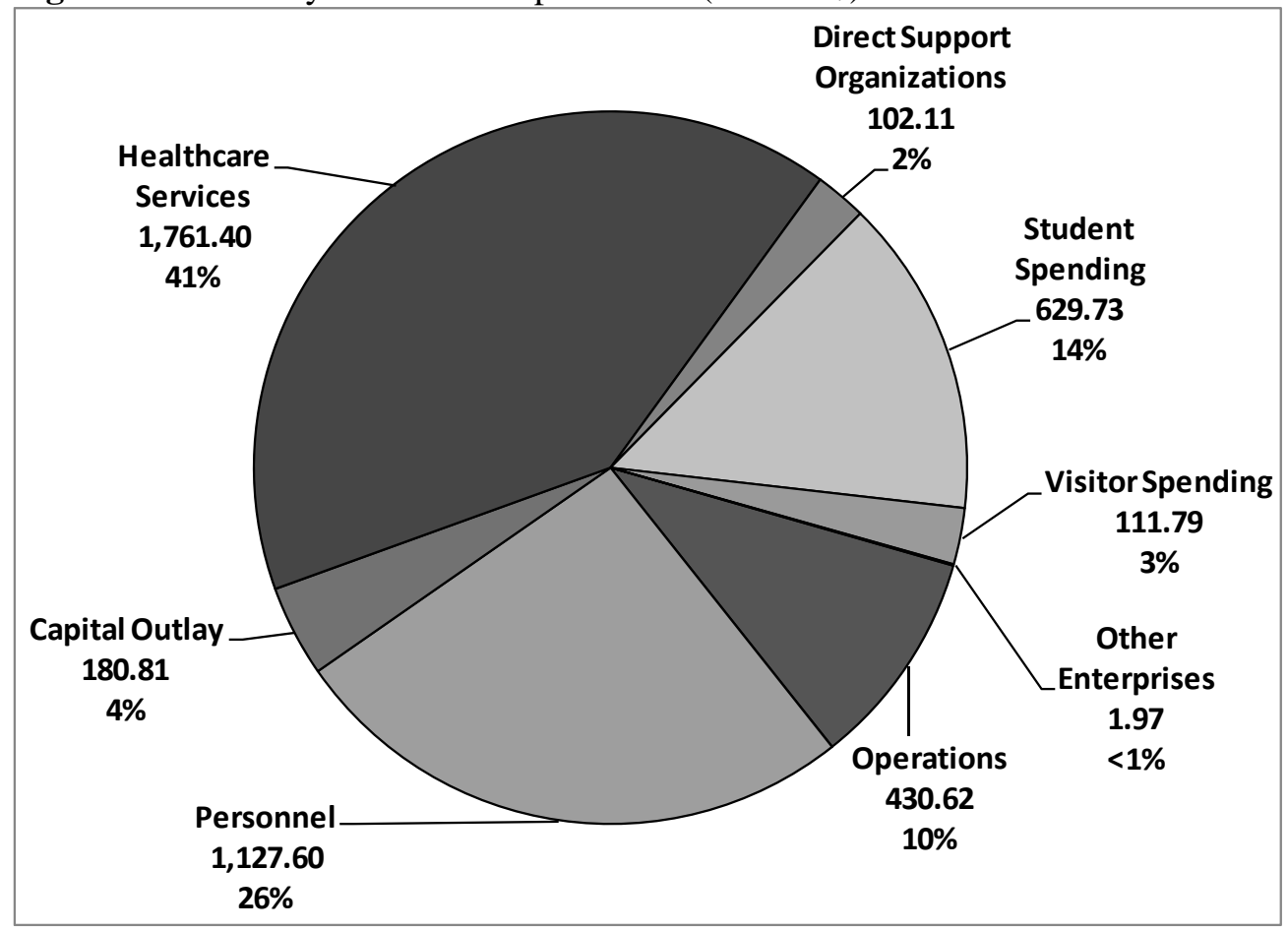

Table 2. Expenditures by University of Florida, Affiliated Organizations, Students, and Visitors in FY 2005-06.

\begin{tabular}{lrrr} 
Activity or Entity & $\begin{array}{r}\text { Total } \\
\text { Expenditures } \\
\text { (million \$) }\end{array}$ & $\begin{array}{c}\text { Expenditures } \\
\text { In-State } \\
\text { (million \$) }\end{array}$ & $\begin{array}{c}\text { Expenditures } \\
\text { from Outside } \\
\text { Sources } \\
\text { (million \$) }\end{array}$ \\
\hline Operations & $\mathbf{4 3 0 . 6 2}$ & $\mathbf{3 1 4 . 0 9}$ & $\mathbf{1 3 8 . 5 1}$ \\
Professional Services & 95.21 & 70.60 & 31.14 \\
Miscellaneous & 89.94 & 78.20 & 34.48 \\
Supplies & 60.74 & 37.16 & 16.39 \\
Utilities & 47.05 & 37.58 & 16.57 \\
Finance \& Insurance & 36.50 & 24.18 & 10.67 \\
Equipment & 30.81 & 17.64 & 7.78 \\
Travel & 29.61 & 22.64 & 9.98 \\
Building Maintenance \& Repair & 22.84 & 14.02 & 6.18 \\
Telecommunications & 9.84 & 5.59 & 2.46 \\
Rentals & 8.09 & 6.47 & 2.85 \\
Personnel & $\mathbf{1 , 1 2 7 . 6 0}$ & $\mathbf{1 , 0 2 4 . 9 9}$ & $\mathbf{4 5 2 . 0 2}$ \\
Faculty \& staff spending & 923.96 & 923.96 & 407.47 \\
Employee benefits \& taxes & 203.64 & 101.03 & 44.55 \\
Capital Outlay & $\mathbf{1 8 0 . 8 1}$ & $\mathbf{1 2 5 . 2 9}$ & $\mathbf{1 1 3 . 2 5}$ \\
Building construction & 102.67 & 100.52 & 100.52 \\
Equipment & 57.24 & 16.67 & 7.35 \\
Library resources & 11.30 & 2.78 & 1.23 \\
Infrastructure construction & 3.83 & 3.24 & 3.24 \\
Furniture & 3.46 & 1.34 & 0.59 \\
Other capital outlay & 2.31 & 0.73 & 0.32 \\
Healthcare Services & $\mathbf{1 , 7 6 1 . 4 0}$ & $\mathbf{1 , 5 9 2 . 0 4}$ & $\mathbf{7 4 8 . 2 6}$ \\
Hospitals & $1,426.14$ & $1,273.54$ & 598.56 \\
Florida Clinical Practice Associates & 151.75 & 144.16 & 67.75 \\
Jacksonville Physicians & 148.51 & 141.08 & 66.31 \\
Jacksonville Healthcare Associates & 19.35 & 18.39 & 8.64 \\
Faculty Dentistry Associates & 11.13 & 10.58 & 4.97 \\
Public Health Professions & 2.98 & 2.83 & 1.33 \\
Veterinary Medicine Associates & 0.93 & 0.88 & 0.41 \\
Other Faculty Practices & 0.61 & 0.58 & 0.27 \\
\hline
\end{tabular}




\begin{tabular}{lrrr} 
Activity or Entity & $\begin{array}{c}\text { Total } \\
\text { Expenditures } \\
\text { (million \$) }\end{array}$ & $\begin{array}{c}\text { Expenditures } \\
\text { In-State } \\
\text { (million \$) }\end{array}$ & $\begin{array}{c}\text { Expenditures } \\
\text { from Outside } \\
\text { Sources } \\
\text { (million \$) }\end{array}$ \\
\hline Direct Support Organizations & $\mathbf{1 0 2 . 1 1}$ & $\mathbf{7 7 . 6 2}$ & $\mathbf{1 8 . 6 3}$ \\
University Athletic Association & 72.19 & 57.61 & 10.72 \\
UF Foundation & 22.47 & 15.03 & 6.25 \\
UF Research Foundation & 2.68 & 1.79 & 1.58 \\
Gator Boosters & 2.41 & 1.61 & 0.04 \\
Other Direct Support Organizations & 2.36 & 1.58 & 0.03 \\
Student Spending & $\mathbf{6 2 9 . 7 3}$ & $\mathbf{6 2 4 . 4 3}$ & $\mathbf{1 6 8 . 9 8}$ \\
Housing (off campus) & 252.40 & 252.40 & 68.30 \\
Food & 135.30 & 135.30 & 36.61 \\
Books, supplies \& computer & 107.31 & 107.31 & 29.04 \\
Personal \& Insurance & 78.15 & 72.85 & 19.72 \\
Clothing & 33.24 & 33.24 & 9.00 \\
Transportation & 23.33 & 23.33 & 6.31 \\
Visitor Spending (non-affiliated) & $\mathbf{1 1 1 . 7 9}$ & $\mathbf{1 1 1 . 7 9}$ & $\mathbf{2 3 . 7 1}$ \\
Campus attractions \& academic events & 73.63 & 73.63 & 17.55 \\
Football games & 32.66 & 32.66 & 3.12 \\
Other Athletic Events & 5.50 & 5.50 & 3.05 \\
Other Enterprises & $\mathbf{2 . 3 6}$ & $\mathbf{1 . 9 7}$ & $\mathbf{1 . 2 0}$ \\
University Village Apartments & 1.22 & 0.85 & 0.85 \\
Baby Gator Childcare & 1.14 & 1.12 & 0.35 \\
\hline Grand Total & $\mathbf{4 , 3 4 6 . 4 1}$ & $\mathbf{3 , 8 7 2 . 2 2}$ & $\mathbf{1 , 6 6 4 . 5 7}$ \\
\hline
\end{tabular}

Note: expenditures by healthcare services, direct support organizations, and other enterprises are for operations, net of transfers to the University; depreciation expense excluded.

Table 3. Operations and Personnel Expenditures by Individual Units of the University of Florida in FY 2005-06

\begin{tabular}{lrrr}
\multicolumn{1}{c}{ Unit } & $\begin{array}{r}\text { Operations } \\
\text { (million \$) }\end{array}$ & $\begin{array}{c}\text { Personnel } \\
\text { (million \$) }\end{array}$ & $\begin{array}{c}\text { Total } \\
\text { (million \$) }\end{array}$ \\
\hline Business Administration & & & \\
Dentistry & 8.20 & 33.15 & 41.35 \\
Design, Construction \& Planning & 7.16 & 33.03 & 40.20 \\
Education & 2.48 & 11.86 & 14.34 \\
Engineering & 8.01 & 23.27 & 31.28 \\
Fine Arts & 42.66 & 83.97 & 126.63 \\
Health and Human Performance & 7.52 & 13.47 & 21.00 \\
Public Health \& Health Professions & 3.23 & 10.36 & 13.58 \\
Agriculture \& Life Sciences (IFAS) & 6.15 & 22.47 & 28.62 \\
Journalism \& Communication & 69.73 & 167.21 & 236.95 \\
Law & 4.43 & 11.95 & 16.38 \\
Liberal Arts and Sciences & 2.92 & 19.75 & 22.67 \\
Medicine & 35.32 & 118.50 & 153.82 \\
Nursing & 62.32 & 244.53 & 306.85 \\
Pharmacy & 2.20 & 8.18 & 10.38 \\
Veterinary Medicine & 11.69 & 15.90 & 27.59 \\
$\quad$ Other Academic Programs & 14.53 & 33.93 & 48.47 \\
Continuing Education & & & \\
Graduate Programs & 17.95 & 10.72 & 28.66 \\
International Programs & 2.25 & 1.62 & 3.87 \\
Jacksonville Medical Center & 0.70 & 1.64 & 2.34 \\
Latin American Studies & 4.14 & 28.76 & 32.90 \\
\hline & 1.40 & 2.07 & 3.46 \\
\hline
\end{tabular}




\begin{tabular}{|c|c|c|c|}
\hline Unit & $\begin{array}{l}\text { Operations } \\
\text { (million \$) }\end{array}$ & $\begin{array}{l}\text { Personnel } \\
\text { (million \$) }\end{array}$ & $\begin{array}{c}\text { Total } \\
\text { (million \$) }\end{array}$ \\
\hline Library & 21.58 & 15.40 & 36.98 \\
\hline Military Studies & 0.07 & 0.15 & 0.22 \\
\hline Sea Grant & 1.80 & 1.56 & 3.36 \\
\hline Sponsored Research & 8.02 & 15.29 & 23.31 \\
\hline Whitney Labs & 1.67 & 3.62 & 5.29 \\
\hline \multicolumn{4}{|l|}{ Social \& Cultural Programs } \\
\hline Florida Museum of Natural History & 3.95 & 9.23 & 13.18 \\
\hline Harn Museum & 0.82 & 1.60 & 2.42 \\
\hline Reitz Union & 2.53 & 3.65 & 6.18 \\
\hline Stephen C. O'Connell Center & 0.75 & 1.26 & 2.01 \\
\hline Student Government & 3.56 & 0.83 & 4.40 \\
\hline Women's Athletics & 0.48 & 0.00 & 0.48 \\
\hline \multicolumn{4}{|l|}{ Support Services } \\
\hline Bridges (Administration) & 10.77 & 9.95 & 20.72 \\
\hline Business Services & 14.91 & 4.97 & 19.88 \\
\hline Construction, Renovation \& Repair & 8.19 & 0.00 & 8.19 \\
\hline Division of Operations Analysis & 0.08 & 0.28 & 0.36 \\
\hline Environmental Health \& Safety & 1.38 & 3.21 & 4.59 \\
\hline Facilities Planning \& Construction & 0.15 & 1.30 & 1.45 \\
\hline Finance and Accounting* & -413.59 & 8.94 & -404.65 \\
\hline Financial Services & 301.71 & 0.00 & 301.71 \\
\hline Housing & 18.91 & 14.67 & 33.58 \\
\hline Human Resources & 0.35 & 4.11 & 4.46 \\
\hline Information Technology & 12.57 & 12.53 & 25.10 \\
\hline Institutional Activities & -6.52 & -0.10 & -6.62 \\
\hline Office of General Counsel & 0.27 & 1.85 & 2.12 \\
\hline Physical Plant & 100.67 & 35.11 & 135.78 \\
\hline Public Relations & 1.09 & 1.71 & 2.79 \\
\hline Registrar's Office & 4.16 & 6.25 & 10.41 \\
\hline Small Business Vendors & 0.08 & 0.11 & 0.19 \\
\hline Student Affairs & 2.98 & 8.10 & 11.08 \\
\hline Student Financial Affairs & 113.40 & 5.11 & 118.52 \\
\hline Student Health Services & 5.29 & 9.90 & 15.20 \\
\hline University Police & 3.26 & 10.15 & 13.41 \\
\hline \multicolumn{4}{|l|}{ Central Administration } \\
\hline Board of Trustees & 0.14 & 0.00 & 0.14 \\
\hline Healthcare Administration & 39.95 & 17.68 & 57.63 \\
\hline President's Office & 0.79 & 2.11 & 2.89 \\
\hline Provost's Office & 17.55 & 8.18 & 25.73 \\
\hline VP Financial Affairs & 2.27 & 4.60 & 6.87 \\
\hline VP Development & 0.02 & 4.38 & 4.40 \\
\hline VP for Governmental Relations & 0.65 & 0.56 & 1.21 \\
\hline
\end{tabular}

*Amount for Finance and Accounting operations includes financial aid received. Amounts for all units include depreciation. 


\section{Total Output Impacts}

The total output, value added and employment impacts associated with the University of Florida are shown in Table 4. These impacts represent not only the direct effects of expenditures, but also the indirect and induced effects calculated using regional economic multipliers for in-state spending funded by revenues from outside sources (see methods).

Total output or revenue impacts amounted to $\$ 5.85$ billion dollars. Among UF entities, some $\$ 2.72$ billion in output impacts, or 46 percent of the total, was for healthcare services, $\$ 1.48$ billion (25\%) was for personal spending by faculty and staff and payroll benefits and taxes, \$664 million (11\%) for student spending, \$502 million (9\%) for University operations, \$282 million (5\%) for capital outlays, \$95 million (2\%) for visitor spending, and \$111 million (2\%) for direct support organizations (Figure 3). In the case of visitor spending, the output impacts were less than actual expenditures because a significant portion of retail purchases leaves the state.

Figure 3. University of Florida Total Output Impacts (million \$)

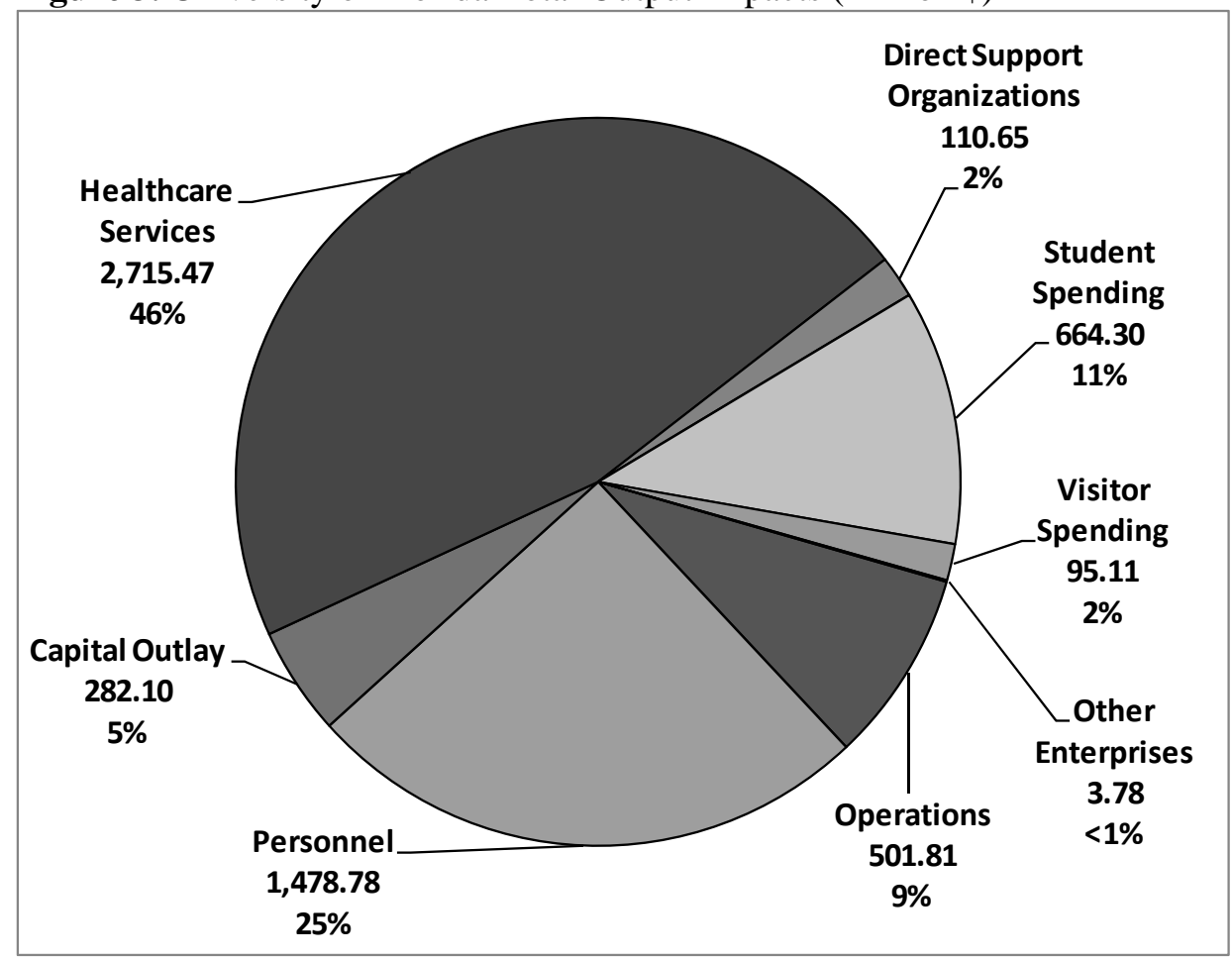


Table 4. Total Output, Value Added and Employment Impacts of the University of Florida, Affiliated Organizations, Students, and Visitors in FY 2005-06.

\begin{tabular}{|c|c|c|c|}
\hline Activity or Entity & $\begin{array}{c}\text { Output } \\
\text { (Revenue) } \\
\text { Impact } \\
\text { (million \$) }\end{array}$ & $\begin{array}{l}\text { Value Added } \\
\text { (Income) } \\
\text { Impact } \\
\text { (million \$) }\end{array}$ & $\begin{array}{c}\text { Employment } \\
\text { Impact } \\
\text { (jobs) }\end{array}$ \\
\hline UF Operations & 501.81 & 269.99 & $\mathbf{4 , 7 9 7}$ \\
\hline Professional Services & 119.43 & 67.74 & 1,500 \\
\hline Miscellaneous & 114.24 & 58.31 & 1,043 \\
\hline Supplies & 59.05 & 26.84 & 508 \\
\hline Utilities & 59.62 & 38.20 & 305 \\
\hline Finance \& Insurance & 41.55 & 19.62 & 277 \\
\hline Equipment & 27.93 & 14.83 & 248 \\
\hline Travel & 36.98 & 20.52 & 458 \\
\hline Building Maintenance \& Repair & 22.66 & 13.10 & 231 \\
\hline Telecommunications & 9.29 & 4.99 & 50 \\
\hline Rentals & 11.06 & 5.83 & 178 \\
\hline UF Personnel & $1,478.78$ & 695.82 & 31,232 \\
\hline Faculty \& staff spending & $1,301.60$ & 622.19 & 9,936 \\
\hline Employee benefits \& taxes & 177.19 & 73.63 & 1,140 \\
\hline Direct Employment & na & na & 20,156 \\
\hline Capital Outlay & 282.10 & 161.57 & 2,883 \\
\hline Building construction & 243.42 & 144.22 & 2,622 \\
\hline Equipment & 23.49 & 9.69 & 135 \\
\hline Library resources & 4.39 & 1.91 & 27 \\
\hline Infrastructure construction & 7.55 & 4.28 & 76 \\
\hline Furniture & 2.05 & 0.86 & 14 \\
\hline Other capital outlay & 1.19 & 0.62 & 8 \\
\hline Healthcare Services & 2,715.47 & $1,562.69$ & 27,222 \\
\hline Hospitals & $2,164.55$ & $1,190.74$ & 21,647 \\
\hline Florida Clinical Practice Associates & 249.44 & 168.52 & 2,522 \\
\hline Jacksonville Physicians & 244.11 & 164.92 & 2,468 \\
\hline Jacksonville Healthcare Associates & 31.81 & 21.49 & 322 \\
\hline Faculty Dentistry Associates & 18.30 & 12.36 & 185 \\
\hline Public Health Professions & 4.89 & 3.31 & 49 \\
\hline Veterinary Medicine Associates & 1.36 & 0.68 & 19 \\
\hline Other Faculty Practices & 1.00 & 0.68 & 10 \\
\hline Direct Employment & na & na & 13,056 \\
\hline Direct Support Organizations & 110.65 & 67.08 & 2,059 \\
\hline University Athletic Association & 75.26 & 52.47 & 1,215 \\
\hline UF Foundation & 27.20 & 11.36 & 640 \\
\hline UF Research Foundation & 4.86 & 2.37 & 94 \\
\hline Gator Boosters & 1.69 & 0.45 & 56 \\
\hline Other Direct Support Organizations & 1.64 & 0.43 & 54 \\
\hline Direct Employment (UFF, Athletics) & na & na & 768 \\
\hline Student Spending & 664.30 & 427.03 & 7,422 \\
\hline Housing (off campus) & 358.04 & 242.38 & 2,932 \\
\hline Food & 118.76 & 64.24 & 2,030 \\
\hline Books, supplies \& computer & 52.81 & 34.33 & 862 \\
\hline Personal \& Insurance & 102.75 & 66.42 & 1,196 \\
\hline Clothing & 20.26 & 12.80 & 264 \\
\hline Transportation & 11.69 & 6.87 & 137 \\
\hline Visitor Spending (non-affiliated) & 95.11 & 55.94 & 1,344 \\
\hline Campus attractions \& academic events & 64.55 & 38.14 & 899 \\
\hline Football games & 23.47 & 13.68 & 346 \\
\hline Other Athletic Events & 7.09 & 4.12 & 99 \\
\hline Other Enterprises & 3.78 & 2.48 & 53 \\
\hline Grand Total & $5,852.01$ & $3,242.60$ & 74,894 \\
\hline
\end{tabular}

Note: total impacts represent direct effect multiplier applied to in-state spending, plus indirect and induced effects multipliers applied to in-state expenditures funded from sources outside Florida. 


\section{Value Added Impacts}

Total value added is an important measure of economic impacts which represents personal income to individuals, business profits, rents, and other property-related income. The total value added impact of the University of Florida amounted to $\$ 3.24$ billion in FY 2005-06. This represented approximately 0.48 percent of the $\$ 673.3$ billion in Gross State Product (GSP) for Florida in 2005. GSP is the broadest measure of economic activity, which is equivalent to the Gross Domestic Product at the national level. Value added impacts for the largest components of the University were \$1.56 billion for healthcare services, \$696 million for UF personnel, \$427 million for student spending, and \$270 million for operations (Figure 4).

Figure 4. University of Florida Value Added Impacts (million \$)

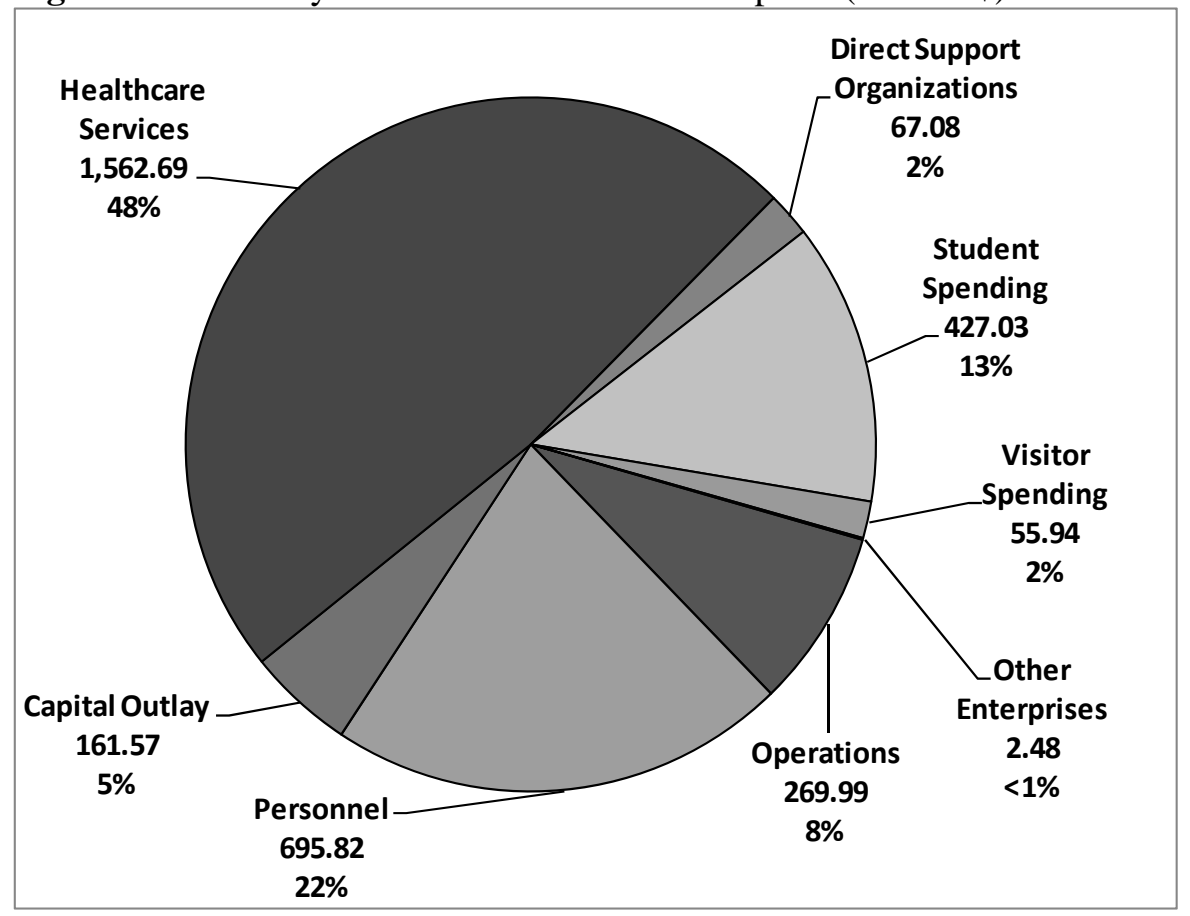

\section{Direct Employment and Employment Impacts}

Employment is an important measure of economic impact. Direct employment at the University of Florida in the Fall semester of 2006 was 20,156 jobs, including 12,373 permanent employees in faculty and staff positions, plus 7,783 in temporary (OPS) positions (Table 5). Among permanent employees, there were 3,183 regular faculty; 1,187 faculty in special positions such as librarians, extension agents, and laboratory school teachers; and about 8,000 support staff in permanent positions (TEAMS and USPS). Employment in Shands Healthcare was 13,056, including 11,777 at large hospitals in Gainesville and Jacksonville, and smaller hospitals in Lake City, Starke, and Live Oak, plus 595 employees at various rehabilitation and elder care facilities, and 684 employees in faculty practice associates (April 2007). The two largest direct support organizations, the University Athletic Association and the UF Foundation, had 776 employees. All together, total direct employment at UF and affiliated organizations was nearly 34,000 jobs. 
In addition to the direct employment at UF and affiliated organizations, spending for University operations, by employee households, students, and visitors, generated 40,906 more jobs in the Florida economy through indirect and induced employment impacts, giving a total employment impact of 74,894 jobs (Table 4). The total employment impact included 31,232 jobs (42\%) associated with direct employment and spending by UF personnel; 25,863 jobs (34\%) for healthcare services; 7,422 jobs (10\%) for student spending; 4,797 jobs (6\%) for UF operations; 2,883 jobs (4\%) for capital outlays; 1,301 jobs (2\%) for direct support organizations; and 1,344 jobs (2\%) for visitor spending (Figure 5).

Figure 5. University of Florida Employment Impacts (jobs)

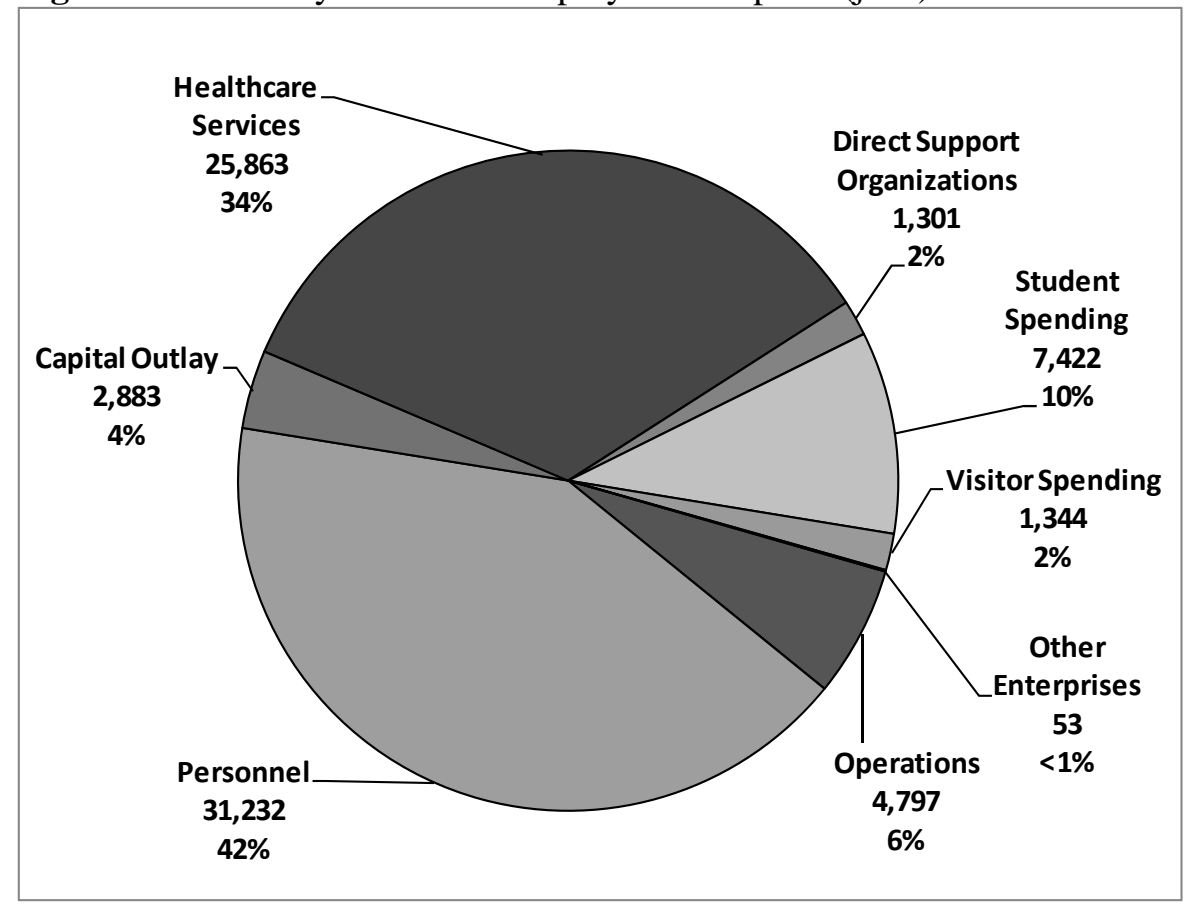

Table 5. Employment at University of Florida and Affiliated Organizations, 2006.

\begin{tabular}{|c|c|}
\hline $\begin{array}{l}\text { Entity/ } \\
\text { Type Employee }\end{array}$ & $\begin{array}{l}\text { Number } \\
\text { Employees }\end{array}$ \\
\hline University of Florida & 20,156 \\
\hline Permanent employees & 12,373 \\
\hline Regular Faculty & 3,183 \\
\hline Other Faculty & 1,187 \\
\hline Librarians & 84 \\
\hline Extension Agents & 291 \\
\hline PK Yonge Laboratory School & 75 \\
\hline Career Faculty & 270 \\
\hline Post Doctoral Research Associates & 467 \\
\hline Support Staff & 8,003 \\
\hline $\begin{array}{l}\text { Technical, Executive, Administrative and } \\
\text { Managerial Support (TEAMS) }\end{array}$ & 5,521 \\
\hline University Support Personnel System (USPS) & 2,482 \\
\hline Temporary Faculty/Staff (OPS) & 7,783 \\
\hline
\end{tabular}




\begin{tabular}{|c|c|}
\hline $\begin{array}{c}\text { Entity/ } \\
\text { Type Employee }\end{array}$ & $\begin{array}{c}\text { Number } \\
\text { Employees }\end{array}$ \\
\hline Shands HealthCare & 13,056 \\
\hline Hospitals & 11,777 \\
\hline Gainesville & 5,585 \\
\hline Alachua General (Gainesville) & 1,469 \\
\hline Jacksonville & 3,868 \\
\hline Lake City & 456 \\
\hline Starke & 231 \\
\hline Live Oak & 168 \\
\hline Other Facilities & 595 \\
\hline Rehab Unit & 148 \\
\hline Vista Pavillion & 283 \\
\hline Home Care & 129 \\
\hline Elder Care & 35 \\
\hline Faculty Group Practices (Gainesville) & 684 \\
\hline Direct Support Organizations & 776 \\
\hline University Athletic Association & 628 \\
\hline UF Foundation & 148 \\
\hline Total UF and Affiliated Organizations & 33,988 \\
\hline
\end{tabular}

Sources: UF Human Resources; Shands Healthcare Human Resources; Univ. Fla. Foundation; Univ. Athletic Association. Note: Employment numbers for Shands HealthCare and Direct Support Organizations exclusive of UF employees.

Employment for Shands HealthCare as of April 2007.

\section{Economic Impacts by Budget Entity}

The University of Florida accounting system tracks expenditures across its major operating divisions and individual departments. Operating and personnel expenditures, and total economic impacts for the major entities in FY 2005-06 are shown in Table 6. The largest entity, known as Education and General (E\&G), which includes most of the individual Colleges and academic units, is here combined with the Physical Plant Division, which is responsible for campus utilities, building and grounds maintenance, etc. This entity had total expenditures of $\$ 813$ million, total output impacts of $\$ 1.02$ billion, and value added impacts of $\$ 507$ million. The Health Science Center, representing the teaching and research functions of the colleges of medicine, dentistry, nursing, pharmacy, health professions, and veterinary medicine, had total expenditures of \$523 million, output impacts of \$675 million, and value added impacts of \$322 million. If the Health Sciences Center/Vet Medicine is combined with the healthcare services provided by Shands Hospitals and Faculty Practice Associates, the total output impact of these entities was $\$ 3.39$ billion. The Institute of Food and Agricultural Sciences (IFAS), representing the College of Agricultural and Life Sciences, the Florida Agricultural Experiment Stations, and the Florida Cooperative Extension Service, had total expenditures of \$222 million, output impacts of \$283 million, and value added impacts of $\$ 136$ million. 
Table 6. Economic Impacts by UF Budget Entity in FY 2005-06.

\begin{tabular}{lrrr} 
UF Budget Entity & $\begin{array}{c}\text { Expenditures } \\
\text { (million \$) }\end{array}$ & $\begin{array}{c}\text { Output } \\
\text { Impact } \\
\text { (million \$) }\end{array}$ & $\begin{array}{c}\text { Value } \\
\text { Added } \\
\text { Impact } \\
\text { (million \$) }\end{array}$ \\
\hline Education \& General, Physical Plant Division & 813.34 & $1,022.88$ & 507.22 \\
Health Science Center, Vet. Medicine & 523.21 & 675.21 & 322.19 \\
Institute of Food and Agricultural Sciences & 221.67 & 282.50 & 136.40 \\
\hline Grand Total & $1,558.22$ & $1,980.60$ & 965.81 \\
\hline
\end{tabular}

\section{Student Attendance and Spending}

Detailed information on University of Florida student enrollment is shown in Table 7. Enrollment for the fall 2005 semester was 50,512 students, of which 43,214 were Florida residents and 7,298 were non-residents. Total cumulative enrollment for the fall, spring, and summer semesters in FY 2005-06 was 122,775 student-semesters, with 65 percent as undergraduate Florida residents, 20 percent as graduate student Florida residents, 5 percent as undergraduate non-residents, and 10 percent as graduate non-residents.

Table 7. UF Student Enrollment by Residency, College level, and Campus Living Status in FY 2005-06.

\begin{tabular}{|c|c|c|c|c|c|c|c|}
\hline \multirow[b]{2}{*}{ Residency and Level } & \multicolumn{3}{|c|}{ Fall Semester } & \multicolumn{4}{|c|}{ Fall, Spring, Summer Semesters } \\
\hline & $\begin{array}{c}\text { On- } \\
\text { campus }\end{array}$ & $\begin{array}{c}\text { Off- } \\
\text { campus }\end{array}$ & Total & $\begin{array}{c}\text { On- } \\
\text { campus }\end{array}$ & $\begin{array}{c}\text { Off- } \\
\text { campus }\end{array}$ & Total & Percent \\
\hline \multicolumn{8}{|c|}{ Resident } \\
\hline Undergraduate & 6,878 & 26,403 & 33,281 & 16,366 & 62,825 & 79,192 & $64.5 \%$ \\
\hline Graduate or Family & 660 & 9,273 & 9,933 & 1,654 & 23,227 & 24,881 & $20.3 \%$ \\
\hline Subtotal & 7,538 & 35,676 & 43,214 & 18,020 & 86,052 & 104,072 & $84.7 \%$ \\
\hline \multicolumn{8}{|c|}{ Non-resident } \\
\hline Undergraduate & 545 & 2,092 & 2,637 & 1,285 & 4,933 & 6,219 & $5.1 \%$ \\
\hline Graduate or Family & 310 & 4,351 & 4,661 & 830 & 11,654 & 12,484 & $10.2 \%$ \\
\hline Subtotal & 855 & 6,443 & 7,298 & 2,115 & 16,588 & 18,702 & $15.2 \%$ \\
\hline Grand total & 8,393 & 42,119 & 50,512 & 20,135 & 102,640 & 122,775 & $100.0 \%$ \\
\hline
\end{tabular}

Sources: Office of Institutional Planning and Research, http://www.ir.ufl.edu/factbook/enroll.htm, http://www.ir.ufl.edu/factbook/tuition.htm; Division of Student Affairs, Housing and Resident Education.

Student expenditures were calculated from cost of attendance data together with enrollment numbers for resident, non-resident, on-campus, and off-campus students in FY 2005-06. Student living expenditures were discounted by 25 percent for the summer semester since the length of this term is 12 weeks instead of 16 . Commissions paid by Food, Vending, and Bookstore service providers were deducted from estimated student and football visitor expenditures. Expenses for on-campus student housing were excluded because these values were captured by general University operations. The proportion of student spending designated as new dollars was determined by the proportion of non-resident students and the proportion of financial aid that originated from outside of Florida. The proportion of student financial aid originating from out-of-State sources was estimated from data on reported in the University of Florida Annual Financial Report. Financial aid designated for University tuition and fees was used to determine the proportion of those payments that originated from outside of Florida, but was not otherwise 
reflected in the impact analysis since these monies were captured by University revenues and spending. When sources of student financial aid were not explicitly identified as either State or Federal, 25 percent was allocated as out-of-State dollars. Financial aid was assumed to be distributed uniformly among all classifications of students, and financial aid from loans, grants, or scholarships was treated identically. Financial aid was allocated between tuition and living expenditures. It was estimated that 50 percent of non-resident students received fee waivers.

Information on student spending is shown in Table 8. The average cost per student-semester for off-campus students was $\$ 6,795$, with housing $(\$ 2,590)$ and food $(\$ 1,160)$ being the largest items. Total student spending was estimated at $\$ 629.7$ million, of which $\$ 55.6$ million was by Florida residents on-campus, $\$ 477.0$ million by Florida residents off-campus, $\$ 6.5$ million by non-residents on-campus, and $\$ 90.7$ million by non-residents offcampus.

Table 8. Student Spending by Residency and Campus Living Status at University of Florida in FY 2005-06.

\begin{tabular}{|c|c|c|c|c|c|c|}
\hline \multirow{2}{*}{ Expense Item } & \multirow{2}{*}{$\begin{array}{c}\text { Average Cost } \\
\text { Per Student } \\
\text { Per Semester }\end{array}$} & \multicolumn{2}{|c|}{$\begin{array}{l}\text { Fla. Resident Student } \\
\text { Spending }\end{array}$} & \multicolumn{2}{|c|}{$\begin{array}{l}\text { Non-Resident Student } \\
\text { Spending }\end{array}$} & \multirow{2}{*}{$\begin{array}{c}\text { Total } \\
\text { Student } \\
\text { Spending } \\
\text { (Million } \\
\$ \text { ) }\end{array}$} \\
\hline & & $\begin{array}{l}\text { On-Campus } \\
\text { (Million } \\
\$ \text { ) }\end{array}$ & $\begin{array}{l}\text { Off-Campus } \\
\text { (Million \$) }\end{array}$ & $\begin{array}{l}\text { On-Campus } \\
\text { (Million } \\
\$ \text { ) }\end{array}$ & $\begin{array}{l}\text { Off-Campus } \\
\text { (Million \$) }\end{array}$ & \\
\hline Books, Supplies, Computers & $\$ 920$ & $\$ 15.81$ & $\$ 75.33$ & $\$ 1.84$ & $\$ 14.32$ & $\$ 107.31$ \\
\hline Food & $\$ 1,160$ & $\$ 19.93$ & $\$ 94.99$ & $\$ 2.32$ & $\$ 18.06$ & $\$ 135.30$ \\
\hline Transportation & $\$ 200$ & $\$ 3.44$ & $\$ 16.38$ & $\$ 0.40$ & $\$ 3.11$ & $\$ 23.33$ \\
\hline Clothing Maintenance & $\$ 285$ & $\$ 4.90$ & $\$ 23.34$ & $\$ 0.57$ & $\$ 4.44$ & $\$ 33.24$ \\
\hline Personal, Insurance & $\$ 670$ & $\$ 11.51$ & $\$ 54.86$ & $\$ 1.34$ & $\$ 10.43$ & $\$ 78.15$ \\
\hline Room (off campus) & $\$ 2,590$ & $\mathrm{Na}$ & $\$ 212.08$ & na & $\$ 40.32$ & $\$ 252.40$ \\
\hline Total & $\$ 6,795$ & $\$ 55.58$ & $\$ 476.98$ & $\$ 6.48$ & $\$ 90.69$ & $\$ 629.73$ \\
\hline
\end{tabular}

Source: UF Office for Student Financial Affairs, http://www.sfa.ufl.edu/pub/forms/cust-5004-07-05A.pdf.

Excludes tuition and fees captured in the University's operating budget. Undergraduate students are assumed to have 15 credit hours, graduate students 12 credit hours. Commissions totaling $\$ 5.14$ million that were paid to the University by oncampus vendors were deducted from student expenditures before calculating impacts. On campus housing expenditures by students were excluded because this value is captured in University operations.

\section{Visitor Attendance and Spending at Athletic Events}

Visitor expenditures were estimated from the number of unaffiliated (not UF student or employee) attendees to UF events, facilities, or attractions, together with average travel expense data for Florida in 2005, as reported by the Florida Visitor Study (Visit Florida USA, published in Florida Statistical Abstract, 2006). Spending by students and visitors at retail establishments such as food stores and general merchandise stores were analyzed to reflect only the retail margin on goods sold. Data on attendance to various athletic events were provided by the University Athletic Association and the management of the O'Connell Center. It was assumed that an average of 4,100 out-of-State fans attended UF home football games, except for the UF - FSU game. Season spending for football assumes 7 home games, including Orange and Blue game attendance at 65 percent of a regular game. Spending for tickets and attendees who are affiliated with the University of Florida were excluded since these expenditures were captured elsewhere in the analysis. Total spending for football is net of University Athletic Association commissions of $\$ 750,000$ from stadium concession sales. 
Information on visitor attendance and spending for all UF athletic events is shown in Table 8, and attendance and spending for UF football games is shown in Table 9. For all athletic events, the total attendance was slightly over 1 million, of which 657 thousand were persons unaffiliated with the University, and 52 thousand were from outside Florida. Total visitor spending was estimated at nearly \$38 million, including \$32 million by in-state visitors and $\$ 6$ million by out-of-state visitors.

Table 8. UF Athletic Event Attendance and Expenditures by Spectators and Teams in FY 2005-06.

\begin{tabular}{lrrr|rrr}
\multicolumn{1}{c}{ Sport } & $\begin{array}{c}\text { Total } \\
\text { Attendance }\end{array}$ & $\begin{array}{c}\text { Unaffiliated } \\
\text { Attendance }\end{array}$ & $\begin{array}{c}\text { Out-of- } \\
\text { State } \\
\text { Attendance }\end{array}$ & $\begin{array}{c}\text { In-State } \\
\text { Visitor } \\
\text { Spending }\end{array}$ & $\begin{array}{c}\text { Out-of-State } \\
\text { Visitor } \\
\text { Spending }\end{array}$ & \multicolumn{1}{c}{$\begin{array}{c}\text { Total } \\
\text { Spending }\end{array}$} \\
\hline Baseball & 122,500 & 61,250 & 2,800 & $\$ 750,006$ & $\$ 324,800$ & $\$ 1,074,806$ \\
Basketball & 178,026 & 89,013 & 1,400 & $\$ 1,089,964$ & $\$ 255,200$ & $\$ 1,345,164$ \\
Football & 603,155 & 456,855 & 27,265 & $\$ 29,353,233$ & $\$ 3,116,390$ & $\$ 32,469,623$ \\
Gymnastics & 17,559 & 8,780 & 600 & $\$ 107,505$ & $\$ 69,600$ & $\$ 177,105$ \\
Soccer & 15,896 & 7,948 & 600 & $\$ 97,323$ & $\$ 76,560$ & $\$ 173,883$ \\
Softball & 10,000 & 5,000 & 1,400 & $\$ 61,225$ & $\$ 162,400$ & $\$ 223,625$ \\
Swimming/Diving & 3,600 & 1,800 & 1,020 & $\$ 22,041$ & $\$ 118,320$ & $\$ 140,361$ \\
Volleyball & 29,774 & 14,887 & 1,000 & $\$ 182,291$ & $\$ 116,000$ & $\$ 298,291$ \\
Other & 22,294 & 11,147 & 16,292 & $\$ 136,495$ & $\$ 1,926,992$ & $\$ 2,063,487$ \\
\hline Total & $1,002,804$ & 656,680 & 52,377 & $\$ 31,800,084$ & $\$ 6,166,262$ & $\$ 37,966,346$ \\
\hline SOH.
\end{tabular}

Sources: University Athletic Association, Stephen C. O'Connell Center, www.gatorzone.com.

Table 9. University of Florida Football Game Attendance and Expenditures in FY 2005-06.

\begin{tabular}{lrrrr}
\multicolumn{1}{c}{ Types of Visitor/attendees } & $\begin{array}{c}\text { Attendance } \\
\text { per game }\end{array}$ & $\begin{array}{c}\text { Spending } \\
\text { per } \\
\text { attendee }\end{array}$ & $\begin{array}{r}\text { Spending } \\
\text { per game }\end{array}$ & $\begin{array}{c}\text { Season Total } \\
\text { Spending }\end{array}$ \\
\hline Unaffiliated attendees & 15,800 & $\$ 116$ & $\$ 1,832,800$ & $\$ 12,009,501$ \\
$\quad \begin{array}{l}\text { Overnight in commercial lodging } \\
\text { Overnight out of State }\end{array}$ & 4,100 & $\$ 116$ & $\$ 475,600$ & $\$ 3,116,390$ \\
$\quad \begin{array}{l}\text { Excursionists and overnight with } \\
\text { friends and family }\end{array}$ & 44,800 & $\$ 59$ & $\$ 2,623,040$ & $\$ 16,936,752$ \\
$\quad$ Local County Residents & 4,000 & $\$ 17$ & $\$ 68,000$ & $\$ 406,980$ \\
$\quad \begin{array}{l}\text { Affilliated attendees } \\
\text { Students }\end{array}$ & 18,000 & na & na & Na \\
$\quad$ Faculty & 4,000 & na & na & Na \\
\hline Total & 90,700 & & $\$ 4,999,440$ & $\$ 32,469,623$ \\
\hline
\end{tabular}

\section{Economic Impacts of Visitors to UF Facilities, Cultural and Academic Events}

Visitor attendance and spending at UF campus facilities and cultural and academic events are shown in Table 10. In FY2005-06, there were a total of 3.5 million visitor-days, of which 2.5 million were by non-affiliated persons. Data on Shands admissions, emergency room visitors, and out-patient visitors were taken from their website. Total spending by in-state visitors was estimated at $\$ 56.1$ million, and spending by out-of-state visitors was $\$ 17.5$ million.

The University of Florida maintains an array of facilities that are used primarily for artistic and cultural events, including the Harn Museum of Art, the Phillips Center for Performing Arts, the Florida Museum of Natural History, the Baughman Center, the University Auditorium, and the Stephen C. O’Connell Center (for concerts). 
Total visitor spending at arts and cultural facilities was estimated to exceed \$14 million, of which half was at the Florida Museum of Natural History (Table 11). Total output impacts were \$9.1 million, value added impacts were $\$ 5.2$ million, and employment impacts were 137 jobs.

Table 10. Visitor Attendance and Spending at Campus Facilities and Academic and Cultural Events, FY 2005-06.

\begin{tabular}{lrrrrr}
\multicolumn{1}{c}{ Facility / Event } & $\begin{array}{c}\text { Total } \\
\text { Visitor } \\
\text { Days }\end{array}$ & $\begin{array}{c}\text { Percent } \\
\text { Non- } \\
\text { Affiliated }\end{array}$ & $\begin{array}{c}\text { Non- } \\
\text { Afilliated } \\
\text { Visitor } \\
\text { Days }\end{array}$ & $\begin{array}{r}\text { Spending by } \\
\text { In-State } \\
\text { Visitors }\end{array}$ & $\begin{array}{c}\text { Spending by } \\
\text { Out-of-State } \\
\text { Visitors }\end{array}$ \\
\hline O'Connell Center Concerts \& Commencement & 82,316 & $72 \%$ & 59,256 & $\$ 3,629,532$ & $\$ 881,629$ \\
Harn Museum of Art & 93,857 & $50 \%$ & 46,929 & $\$ 2,746,878$ & $\$ 54,437$ \\
Phillips and Baughman Centers, Univ. Auditorium & 125,000 & $50 \%$ & 62,500 & $\$ 3,693,876$ & $\$ 72,500$ \\
Florida Museum of Natural History & 250,000 & $50 \%$ & 125,000 & $\$ 7,021,034$ & $\$ 725,000$ \\
Career Resource Center & 1,214 & $100 \%$ & 1,214 & $\$ 130,296$ & $\$ 140,824$ \\
Preview for Freshmen, transfers and family & 16,200 & $100 \%$ & 16,200 & $\$ 2,565,325$ & $\$ 519,511$ \\
Family weekend & 2,400 & $100 \%$ & 2,400 & $\$ 436,695$ & $\$ 84,818$ \\
Athletic and Band camps & 10,400 & $90 \%$ & 9,360 & Na & na \\
UF Conferences & 28,870 & $86 \%$ & 24,810 & $\$ 1,654,977$ & $\$ 1,988,472$ \\
Medical College Conf. \& Continuing Ed. & 7,093 & $80 \%$ & 5,674 & $\$ 609,019$ & $\$ 658,230$ \\
College of Dentistry Conf. \& Continuing Ed. & 2,800 & $80 \%$ & 2,240 & $\$ 240,414$ & $\$ 259,840$ \\
College of Pharmacy & 37,200 & $90 \%$ & 33,480 & $\$ 1,028,213$ & $\$ 1,941,840$ \\
IFAS Conferences: & 5,851 & $70 \%$ & 4,096 & $\$ 535,503$ & $\$ 95,020$ \\
Shands Hospital Admissions & 88,519 & $75 \%$ & 66,389 & Na & na \\
Shands Hospital Emergency Room Visits & 216,215 & $75 \%$ & 162,161 & $\$ 1,803,947$ & $\$ 771,239$ \\
Shands Hospital Outpatient Visits & $1,114,658$ & $75 \%$ & 835,994 & $\$ 9,299,926$ & $\$ 3,975,985$ \\
Shands Hospital Accompanying Friends and & $1,419,392$ & $75 \%$ & $1,064,544$ & $\$ 20,690,431$ & $\$ 5,378,719$ \\
$\quad$ Relatives & $3,501,985$ & & $2,522,246$ & $\$ 56,086,065$ & $\$ 17,548,181$ \\
\hline Total & & &
\end{tabular}

Sources: Stephen C. O'Connell Center, Shands Hospital; UF Conferences Dept.; Dean of Students Office; Fla. Museum of Natural History; Gainesville Visitors and Convention Bureau; UF Dept of Recreation, Tourism and Sports; IFAS Office of Conferences and Institutes; University Performing Arts Center; College of Medicine Continuing Education; College of Dentistry, Continuing Education; College of Pharmacy, Continuing Education.

Table 11. Visitor Spending Impacts for UF Arts and Cultural Facilities in FY 2005-06.

\begin{tabular}{lrrrr}
\multicolumn{1}{c}{ Venue } & $\begin{array}{c}\text { Total } \\
\text { Spending } \\
(\$ 000)\end{array}$ & $\begin{array}{c}\text { Output } \\
\text { Impact } \\
(\$ 000)\end{array}$ & $\begin{array}{c}\text { Value } \\
\text { Added } \\
\text { Impact } \\
(\$ 000)\end{array}$ & $\begin{array}{r}\text { Employment } \\
\text { Impact (jobs) }\end{array}$ \\
\hline O'Connell Center Concerts & 587 & 353 & 200 & 5.5 \\
Harn Museum of Art & 2,747 & 1,654 & 938 & 25.7 \\
Phillips Performing Arts Center, Baughman & 3,694 & 2,230 & 1,266 & 34.6 \\
$\quad$ Center, University Auditorium & 7,021 & 4,820 & 2,763 & 71.5 \\
Florida Museum of Natural History & 14,048 & 9,058 & 5,167 & 137.2 \\
Total & & & & \\
\hline
\end{tabular}




\section{Regional Employment}

The University of Florida is concentrated at the main campus in Gainesville, but has operations statewide at UF/IFAS Research and Education Centers, Extension Offices in all 67 counties, and at Shands Hospitals or clinics. Table 11 shows budgeted fulltime equivalent (FTE) employment for UF by region of residence in Florida (Figure 6). Of course, the vast majority of employees $(21,098)$ reside in the Gainesville region. There was also significant employment in the Jacksonville area $(4,430)$, mainly associated with the Shands Hospital.

Figure 6. Florida Economic Regions

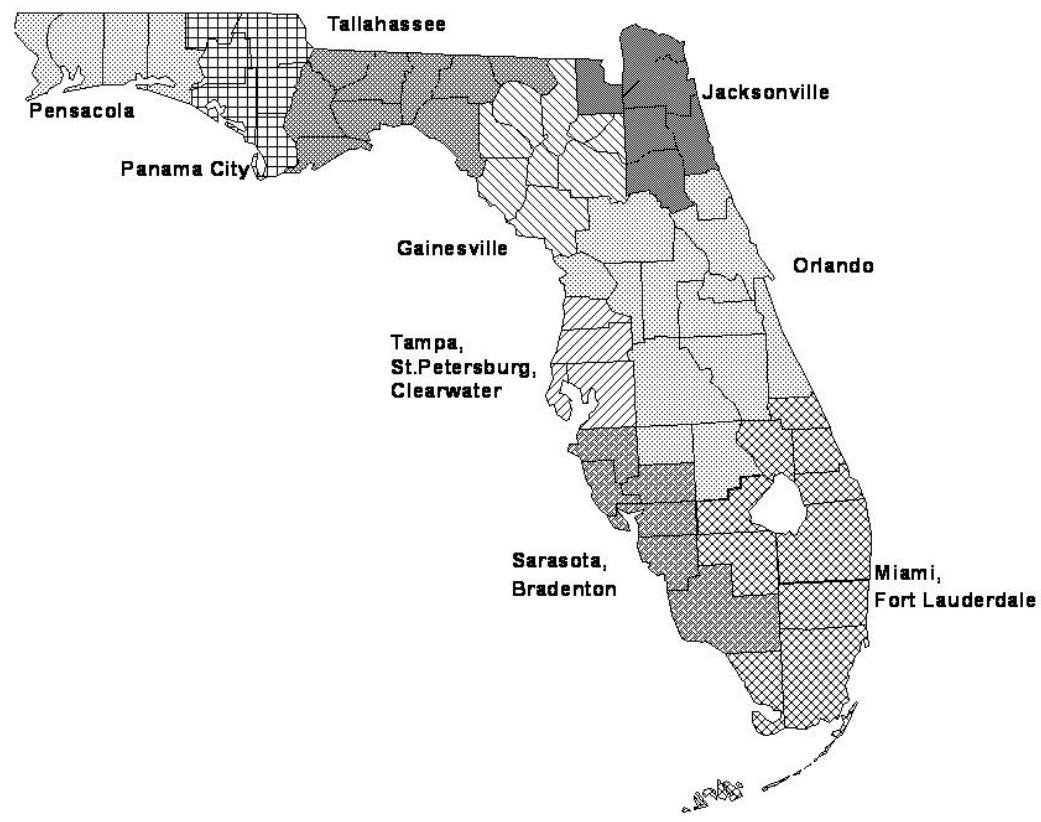

Table 11. Regional Employment by University of Florida and Affiliated Organizations, 2006.

\begin{tabular}{lr}
\multicolumn{1}{c}{ Region of Residence } & $\begin{array}{c}\text { Number } \\
\text { Employees }\end{array}$ \\
\hline Gainesville & 21,098 \\
Jacksonville & 4,430 \\
Orlando & 454 \\
Miami-Fort Lauderdale & 271 \\
Tallahassee & 109 \\
Tampa-St. Petersburg & 89 \\
Sarasota-Bradenton & 84 \\
Pensacola & 62 \\
Panama City & 36 \\
Outside Florida & 20 \\
Not Available & 417 \\
\hline Total & 27,071 \\
\hline Soure: UF Office
\end{tabular}

Source: UF Office of the Provost, March 2006; Shands Health Care.

Regions are defined by the U.S. Department of Commerce, Bureau of Economic Analysis. Data for UF reflect budgeted permanent fulltime equivalent (FTE) employment at UF as of March 2006; does not include temporary employees; Shands HealthCare employees were assumed to reside in the Gainesville area, except for hospital at Jacksonville; UF Foundation and Athletic Association employees assumed to reside in Gainesville area. 


\section{Economic Impacts in Alachua County, Florida}

A separate analysis was conducted on the economic impacts of the University of Florida in Alachua County, Florida, the county in which its main campus is located. The methods used for this supplementary analysis were identical to those used in evaluating the University's impacts on the State, although the data used were modified to represent only Alachua County instead of the State of Florida. An IMPLAN model was constructed for Alachua County to provide economic multipliers that were applied against expenditures. The proportion of revenues or sources of funds originating from outside Alachua County was estimated at \$3.92 billion, or 99.2 percent of total revenues. Student expenditures funded from outside sources, exclusive of financial aid and loans, were estimated by the proportion of students whose home residence was outside the County (89.3\%). ${ }^{5}$ The number of visitors from outside Alachua County was estimated from information for each venue, or based on the proportion of the State's population residing outside the County (98.7\%). ${ }^{6}$ Expenditures by UF and related organizations that occurred within Alachua County excluded spending by entities outside the County, such as Shands Hospitals in Bradford, Columbia, Duval, and Suwannee Counties, ${ }^{7}$ and payroll spending by employees residing outside Alachua County. ${ }^{8}$

Estimated expenditures related to the University in Alachua County, along with total economic impacts, are shown in Table 12. Approximately $\$ 2.84$ billion, or 65 percent of all University related expenditures, were estimated to occur within the County, of which $\$ 2.77$ billion, or nearly 98 percent, were funded from sources outside the County. Total output or revenue impacts in Alachua County were estimated at $\$ 4.95$ billion for the 2005-06 fiscal year, while value-added impacts were $\$ 2.80$ billion. Direct employment in the County by UF, Shands and Direct Support Organizations was 25,441 jobs, and total employment impacts were nearly 65 thousand jobs. This employment impact represented approximately 42 percent of all jobs in the County in 2005, as reported by the Bureau of Economic Analysis. ${ }^{9}$ Among the different University entities, Healthcare Services was responsible for the largest share of economic impacts in the County, with nearly \$1.99 billion in output impacts, \$1.17 billion in value-added impacts, and 19,217 jobs. Impacts in the County associated with spending by UF employees were $\$ 1.34$ billion in output, \$636 million in value-added, and 24,757 jobs. Clearly, the University of Florida represents the most significant source of economic activity by a single entity within the County.

\footnotetext{
${ }^{5}$ University of Florida Office of Institutional Planning and Research, “Geographic Distribution of Enrollment by Florida Counties”, http://www.ir.ufl.edu/factbook/i-06_hist.pdf (average of 2005 and 2006 fall terms).

${ }^{6}$ U.S. Bureau of Census, "Population Estimates by County”, http://www.census.gov/popest/counties/CO-EST2006-01.html.

${ }^{7}$ Shands Teaching Hospital and Clinics, Inc., "Consolidated Financial Statements”, http://shands.org/about/reports/Fiscal.pdf

${ }^{8}$ University of Florida, Office of the Provost and Office of Institutional Planning and Research.

${ }^{9}$ U.S. Department of Commerce, Bureau of Economic Analysis, Regional Economic Accounts, www.bea.gov/bea/regional/reis/default.cfm\#a
} 
Table 12. Expenditures and Economic Impacts of University of Florida, Affiliated Organizations, Students, and Visitors in Alachua County, Florida, FY 2005-06.

\begin{tabular}{|c|c|c|c|c|}
\hline Activity or Entity & $\begin{array}{l}\text { Spending } \\
\text { In-County } \\
\text { (million \$) }\end{array}$ & $\begin{array}{c}\text { Output } \\
\text { (Revenue) } \\
\text { Impact } \\
\text { (million \$) }\end{array}$ & $\begin{array}{l}\text { Value Added } \\
\text { (Income) } \\
\text { Impact } \\
\text { (million \$) }\end{array}$ & $\begin{array}{c}\text { Employment } \\
\text { Impact } \\
\text { (jobs) }\end{array}$ \\
\hline Operations & 267.10 & 508.37 & 283.36 & 6,025 \\
\hline Professional Services & 61.46 & 126.37 & 71.10 & 1,896 \\
\hline Miscellaneous & 76.53 & 126.60 & 64.25 & 1,364 \\
\hline Supplies & 17.83 & 34.09 & 18.34 & 439 \\
\hline Utilities & 32.47 & 61.27 & 40.49 & 463 \\
\hline Finance \& Insurance & 24.09 & 51.84 & 26.60 & 428 \\
\hline Equipment & 10.91 & 21.20 & 12.63 & 256 \\
\hline Travel & 16.66 & 32.39 & 18.32 & 532 \\
\hline Building Maintenance \& Repair & 16.07 & 31.64 & 18.38 & 379 \\
\hline Telecommunications & 5.23 & 11.13 & 6.34 & 85 \\
\hline Rentals & 5.85 & 11.84 & 6.90 & 182 \\
\hline Personnel & 831.14 & 1,336.29 & 636.44 & 24,757 \\
\hline Faculty \& staff spending & 763.93 & $1,205.51$ & 577.12 & 5,939 \\
\hline Employee benefits \& taxes & 67.21 & 130.79 & 59.33 & 703 \\
\hline Direct UF Employment & & & & 18,115 \\
\hline Capital Outlay & 113.01 & 218.64 & 125.40 & 2,645 \\
\hline Building construction & 94.61 & 188.62 & 112.38 & 2,404 \\
\hline Equipment & 11.59 & 17.61 & 7.21 & 119 \\
\hline Library resources & 3.42 & 6.02 & 2.22 & 50 \\
\hline Infrastructure construction & 2.71 & 5.05 & 2.87 & 60 \\
\hline Other capital outlay & 0.68 & 1.34 & 0.71 & 13 \\
\hline Healthcare Services & $1,002.55$ & $1,988.58$ & $1,174.05$ & 19,217 \\
\hline Hospitals & 843.52 & $1,658.37$ & 948.66 & 10,370 \\
\hline Florida Clinical Practice Associates & 144.16 & 299.60 & 204.75 & 1,980 \\
\hline Faculty Dentistry Associates & 10.58 & 21.98 & 15.02 & 145 \\
\hline Public Health Professions & 2.83 & 5.88 & 4.02 & 39 \\
\hline Veterinary Medicine Associates & 0.88 & 1.54 & 0.78 & 8 \\
\hline Other Faculty Practices & 0.58 & 1.21 & 0.82 & 8 \\
\hline Direct Healthcare Employment & & & & 6,666 \\
\hline Direct Support Organizations & 77.34 & 165.48 & 104.59 & 1,834 \\
\hline University Athletic Association & 57.49 & 124.52 & 87.41 & 889 \\
\hline UF Foundation & 15.03 & 31.02 & 13.01 & 216 \\
\hline UF Research Foundation & 1.79 & 3.71 & 1.56 & 26 \\
\hline Gator Boosters & 1.61 & 3.32 & 1.39 & 23 \\
\hline Other Direct Support Organizations & 1.41 & 2.91 & 1.22 & 20 \\
\hline Direct Support Organization Employment & & & & 660 \\
\hline Student Spending & 456.70 & 642.89 & 416.03 & 8,850 \\
\hline Housing (off campus) & 148.58 & 315.37 & 216.36 & 3,325 \\
\hline Food & 124.51 & 143.56 & 79.49 & 2,633 \\
\hline Books, supplies \& computer & 99.36 & 70.12 & 46.04 & 1,223 \\
\hline Personal \& Insurance & 38.91 & 77.99 & 51.39 & 1,206 \\
\hline Clothing & 24.09 & 21.07 & 13.67 & 332 \\
\hline Transportation & 21.25 & 14.77 & 9.08 & 132 \\
\hline Visitor Spending (non-affiliated) & 87.52 & 91.46 & 53.93 & 1,519 \\
\hline Campus attractions \& academic events & 57.38 & 57.51 & 33.85 & 964 \\
\hline Football games & 25.73 & 28.96 & 17.27 & 466 \\
\hline Other Athletic Events & 4.41 & 4.99 & 2.81 & 89 \\
\hline Other Enterprises & 1.86 & 3.08 & 2.09 & 55 \\
\hline Grand Total & $2,837.21$ & $4,954.79$ & $2,795.90$ & 64,902 \\
\hline
\end{tabular}

Note: expenditures by healthcare services, direct support organizations, and other enterprises are for operations, net of transfers to the University; depreciation expenses excluded; total impacts are reflect in-county spending, plus indirect and induced effects multiplier effects of in-county spending from sources outside the County. 